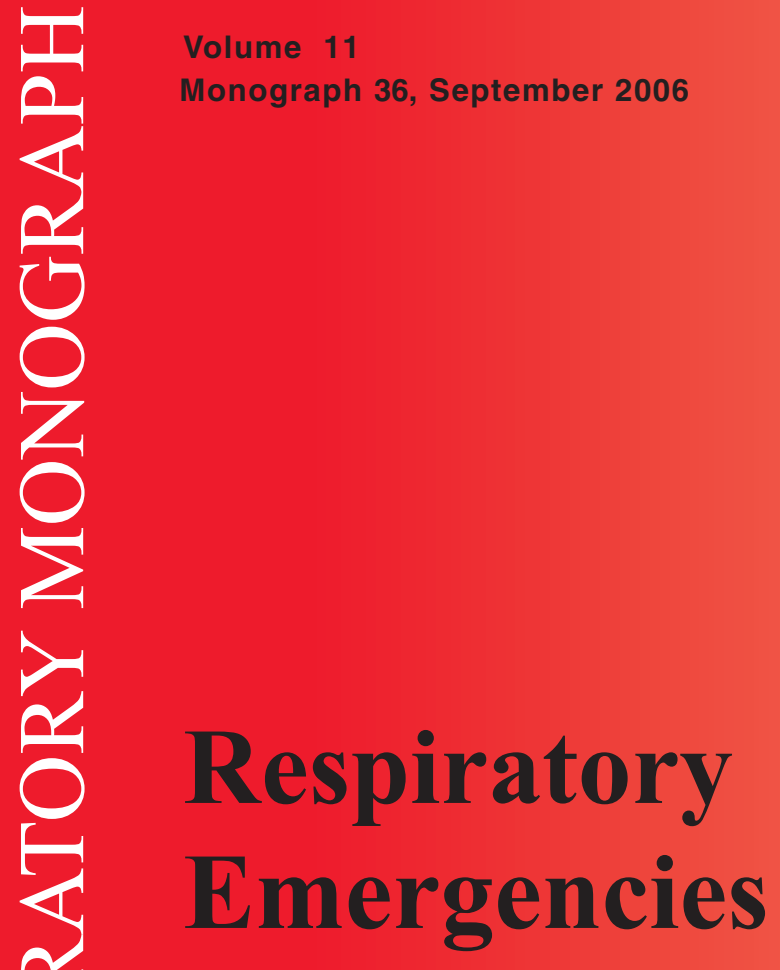

$\frac{\rho}{2}$

Edited by

S. Nava and T. Welte

$\frac{Z}{4}$

II

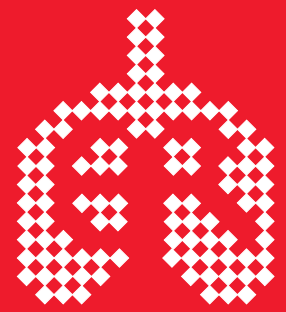

EUROPEAN RESPIRATORY

SORurétásed by ,

From: European Respiratory Society Publications (reader.ersjournals.com) 


\section{Respiratory Emergencies}

Purchased by,

From: European Respiratory Society Publications (reader.ersjournals.com) 
European Respiratory Monograph 36

September 2006

\author{
Editor in Chief
}

K. Larsson

This book is one in a series of European Respiratory Monographs. Each individual issue provides a comprehensive overview of one specific clinical area of respiratory health, communicating information about the most advanced techniques and systems needed to investigate it. It provides factual and useful scientific detail, drawing on specific case studies and looking into the diagnosis and management of individual patients. Previously published titles in this series are listed at the back of this book with details of how they can be purchased.

Purchased by ,

From: European Respiratory Society Publications (reader.ersjournals.com) 


\title{
Respiratory Emergencies
}

\author{
Edited by \\ S. Nava and T. Welte
}

Purchased by,

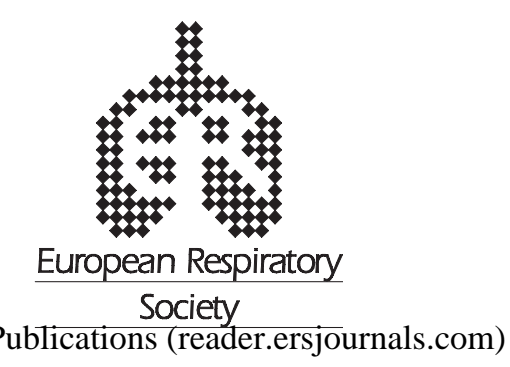


Published by European Respiratory Society Journals Ltd (C2006

September 2006

Hardback ISBN: 1-904097-38-3

Paperback ISBN: 1-904097-42-1

ISSN: $1025-448 \mathrm{x}$

Printed by The Charlesworth Group, Wakefield, UK

Business matters (enquiries, advertisement bookings) should be addressed to: European Respiratory Society Journals Ltd, Publications Office, Suite 2.4, Hutton's Building, 146 West Street, Sheffield, S1 4ES, UK. Fax: 441142780501.

All material is copyright to European Respiratory Society Journals Ltd. It may not be reproduced in any way including electronic means without the express permission of the company.

Statements in the volume reflect the views of the authors, and not necessarily those of the European Respiratory Society, editors or publishers.

Purchased by ,

From: European Respiratory Society Publications (reader.ersjournals.com) 


\section{CONTENTS}

The Guest Editors vii

Preface viii

Introduction $\quad$ ix

1. Hypoxic and hypercapnic respiratory failure $\quad 1$

P. Ceriana, S. Nava

2. Exacerbation of obstructive lung diseases: therapy 16

J.R. Hurst, J.A. Wedzicha

3. Ventilation in obstructive lung disease $\quad 34$

T. Köhnlein, T. Welte

4. Acute respiratory distress syndrome $\quad 49$

J.J. Haitsma

5. Inhalation injury

U. Molitoris, P.M. Vogt, K. Raymondos

6. Extrapulmonary causes of respiratory failure including acute neuromuscular disorders

A.K. Simonds

7. Management of massive haemoptysis

J. Theron, A.H. Diacon, C.T. Bolliger

8. Tracheobronchial aspiration

O. Dikensoy, H. Misra, E. Ekinci, R.W. Light

9. Drowning

D.A. Groneberg, J-L. Vincent, T. Welte

F. Reichenberger, C. Nachtmann, F. Grimminger

11. Pneumothorax and bronchopleural fistula

M. Noppen

12. Emergencies in interstitial and immunological lung disease M. Kolb, G. Cox 
13. Emergency treatment of community-acquired pneumonia

M. Valencia, J. Sellares, A. Torres

14. Pneumonia in the immunocompromised patient

H. Kothe, K. Dalhoff

15. Paediatric emergencies

D. Corrigan, J.Y. Paton

16. Acute respiratory failure during pregnancy

N.A. Hanania, M. Cazzola

Purchased by ,

From: European Respiratory Society Publications (reader.ersjournals.com) 


\section{Previously published in the European Respiratory Monograph Series:}

Cystic Fibrosis

Edited by A K Webb, F A Ratjen (2006)

Pulmonary Manifestations of Systemic Diseases, Monograph 34

Edited by $G M$ Verleden, $M G$ Demedts, $R$ Westhovens, M Thomer (2005)

Diagnosis, Prevention and Treatment of Exercise-Related Asthma, Respiratory and Allergic Disorders in Sports, Monograph 33 Edited by K-H Carlsen, L Delgado, S Del Giacco (2005)

Sarcoidosis, Monograph 32

Edited by M Drent, U Costabel (2005)

Lung Function Testing, Monograph 31

Edited by R Gosselink, H Stam (2005)

Imaging, Monograph 30

Edited by A Bankier, P A Gevenosis (2004)

Surgery for Non-Neoplastic Disorders of the Chest: a Clinical Update, Monograph 29

Edited by $G M$ Verleden, D Van Raemdonck, T Lerut, M Demedts (2004)

Antibiotics and the Lung, Monograph 28 Edited by M Cazzola, F Blasi, S Ewig (2004)

Pulmonary Vascular Pathology: A Clinical Update, Monograph 27

Edited by $M$ Demedts, $M$ Delcroix, $R$ Verhaeghe, G M Verleden (2004)

Lung Transplantation, Monograph 26

Edited by J Boe, M Estenne, W Weder (2003)

Respiratory Diseases in Women, Monograph 25 Edited by C Mapp, S Buist (2003)

Nutrition and Metabolism in Respiratory Disease, Monograph 24

Edited by J Boe, M Estenne, W Weder (2003)

Asthma, Monograph 23

Edited by F Chung, L M Fabbri (2003)

Pleural Diseases, Monograph 22

Edited by R Loddenkemper, V B Antony (2002)
The Impact of Air Pollution on Respiratory Health, Monograph 21

Edited by G D'Amato, S T Holgate (2002)

ARDS, Monograph 20

Edited by $T$ W Evans, $M J D$ Griffiths, B F Keogh (2002)

Growing up with Lung Disease: The Lung in Transition to Adult Life, Monograph 19

Edited by A Bush, K-H Carlsen, M S Zach (2002)

The Nose and Lung Diseases, Monograph 18

Edited by B Wallaërt, P Chanex, P Godard (2001)

Lung Cancer, Monograph 17

Edited by S G Spiro (2001)

Noninvasive Mechanical Ventilation, Monograph 16

Edited by J-F Muir, N Ambrosino, A K Simonds (2001)

Interstitial Lung Diseases, Monograph 14

Edited by D Olivieri, $R$ M du Bois (2000)

Pulmonary Rehabilitation, Monograph 13

Edited by C F Donner, M Decramer (2000)

Respiratory Mechanics, Monograph 12

Edited by J Milic-Emili (1999)

Occupational Lung Disorders, Monograph 11

Edited by C E Mapp (1999)

Respiratory Disorders During Sleep, Monograph 10

Edited by W T McNicholas (1998)

Pulmonary Endoscopy, Monograph 9

Edited by J Strausz (1998)

Mechanical Ventilation from Intensive Care to Home Care, Monograph 8

Edited by C Roussos (1998)

Management of COPD, Monograph 7

Edited by D S Postma, N M Siafakas (1998)

Clinical Exercise Testing, Monograph 6

Edited by J Roca, B J Whipp (1997)

Monographs may be purchased from:

Publications Sales Department, Maney Publishing, Suite 1C, Joseph’s Well, Hanover Walk, Leeds, LS3 $1 \mathrm{AB}$, UK.

Tel: 44 (0)113 2432800; Fax: 44 (0)113 3868178; E-mail: books@maney.co.uk; www.maney.co.uk Customers in the Americas should contact: Old City Publishing Inc., 628 North 2nd Street, Philadelphia PA 19123, USA. Tel: 1215925 4390; Fax: 1215925 4371; E-mail: info@oldcitypublishing.com 


\section{EUROPEAN RESPIRATORY MONOGRAPH}

\section{Instructions to Authors}

The European Respiratory Monograph is an official publication of the European Respiratory Society, which publishes "state of the art" review articles, only by invitation, under the coordination of a Guest Editor(s). All manuscripts should be sent in electronic format to: monograph@ersj.org.uk

Offers or queries regarding future content should be directed to the Editor in Chief: K. Larsson, Unit of Lung and Allergy Research, Division of Physiology, National Institute of Environmental Medicine, IMM, SE17177 Stockholm, Sweden. Fax: 46 8300619. E-mail: Kjell.Larsson@ki.se

\section{INSTRUCTIONS FOR THE PREPARATION OF MANUSCRIPTS}

\section{Presentation}

The manuscript should be accompanied by a presentation letter and a title page, with the name of the authors and their affiliation, the full mailing address, fax number and e-mail address of the corresponding author, and any source of support. A short running head should be given and not more than 6 keywords. The length of a chapter, in typescript form, should be approximately 20-30 pages of double-spaced type including text, figures, tables and references.

\section{Text}

Experimental paper format is not required, and should not include sections on methods, results and discussion. Headings and subheadings should be used to facilitate the readers. The Monograph aims to be educational. Clear distinction should be made between strong information (i.e. based on random, controlled clinical trials) and soft information (i.e. suggestive but inconclusive data). The text should start with an introduction and finish with a 10-15 line conclusion. A brief summary (no more than 300 words) is required with the typescript which should recapitulate the key points, rather than introducing the subjects to be discussed.

\section{Tables and illustrations}

Please include all tables and figures with your typescript. Each chapter must include at least one table or illustration. Every table and illustration must be cited in the text. The source of reproduction must be acknowledged (from [Ref. No.] with permission). See copyright information below.

\section{Tables}

Each table should be typed on a separate page and should have a short title. Other information should appear as footnotes to the table, indicated by superscript symbols. Large tables are difficult to read and print, and should be avoided.

\section{Illustrations}

Where a figure can replace or reduce a text passage, the figure is preferred. Figures should be named and numbered. Line drawings can be supplied as .jpeg, .gif, .tif or .btmp, and will be redrawn into house style. All photographic images should be provided with a minimum of 300 dots per inch (dpi) and should preferably be supplied in .jpeg, tif or .eps format. Photomicrographs must have internal scale markers (linear scale). Please provide a clear legend for each figure which should be brief and nonrepetitive of information given in the text, all abbreviations should be expanded in the legend.

\section{References}

The author is free to decide on how many references he/she will use. References to original work are preferred to references or quotations from other chapters in the Monograph. However, the author is free to decide on what he/she will quote. Number references consecutively in the order in which they are first mentioned in the text, including those mentioned in tables and figures. Type the references in square brackets. Cite personal communications and unpublished work in the text only, giving the name and initials of the authors and the year of writing. Follow the style of the European Respiratory Journal (Vancouver style).

\section{Copyright}

You must obtain from the copyright holder (usually the publisher of the work) permission to reproduce figures, tables and extended quotations. The source of any such reproduction must always be acknowledged. The original document should be included with your manuscript to the Editor in Chief.

For any further details please refer to the instructions to the authors of the European Respiratory Purchlouscd by,

From: European Respiratory Society Publications (reader.ersjournals.com) 


\section{Preface}

Access to free airways is the first consideration in emergency situations, such as at the scene of an accident, and respiratory emergencies represent an important part of acute medicine in general. Respiratory problems also play a crucial part in critical care medicine and constitute an important share of the numerous problems in an intensive care unit. As breathing difficulties are experienced with anguish, these symptoms can generally be very frightening, particularly to those suffering from them. It seems reasonable to assume that respiratory emergencies are mostly handled by physicians specialised in respiratory diseases. However, this is far from the case and the tradition in this regard varies from country to country. In some countries, there is close collaboration between respiratory and intensive care units, whereas in other countries this collaboration is occurs less frequently. It may also be problematic finding novel scientific achievements within the field of respiratory emergencies since there is no clear forum for these kinds of publications. The number of scientific papers emphasising respiratory emergencies finding their way into respiratory journals is not overwhelming, which is a pity and is something that we could, and should, try to change in the future.

As a result, those interested in respiratory emergencies who are searching for compiled information focused in this field have to put in a great deal of work seeking information from various sources. Therefore, it is very satisfying and a great pleasure to announce this issue of European Respiratory Monograph on respiratory emergencies. In this issue of the monograph, different aspects of respiratory emergencies have been covered by the best specialists in the field. The Monograph gives insights into acute respiratory events due to exacerbations of obstructive pulmonary diseases, infections, accidents, neuromuscular disorders, acute respiratory distress syndrome, and much else. It is my hope that it will reach many readers and that it may help to throw a bridge across between specialists in respiratory and intensive care medicine.

\section{K. Larsson \\ Editor in Chief}

Eur Respir Mon, 2006, 36, viii. Printed in UK - all rights reserved. Copyright ERS Journals Ltd 2006; European Respiratory Monograph; ISSN 1025-448x.

Purchased by , 


\title{
INTRODUCTION
}

\author{
S. Nava*, T. Welte
}

* Respiratory Intensive Care Unit, S. Maugeri Foundation, Scientific Institute for Research and Care, Pavia, Italy. Fax: 39 0382592075; E-mail: snava@fsm.it; " Dept of Respiratory Medicine, Hannover Medical School, Hannover, Germany. Fax: 49 5115328532; E-mail: tobias.welte@gmx.de

Emergency medical admissions constitute a substantial proportion of the workload of the respiratory and cardiology wards, and of the emergency departments. Mortality among these patients is significant and may be determined by the quality of care provided. According to the risk stratification of the patients, the mortality rate may vary from $1 \%$ to $>30 \%$. Interestingly enough, among the numerous variables associated with in-hospital mortality, two of the most powerful independent predictors are respiratory rate and oxygen saturation, suggesting that the respiratory system is very often involved either as a primary trigger of the emergency or as a secondary target of another organ's acute dysfunction.

Most pulmonologists or intensivists, when asked about what they consider to be a respiratory emergency, are likely to suggest the occurrence of acute respiratory failure, either "purely hypoxic" or hypercapnic.

It follows that the main causes of acute respiratory problems are considered to be an exacerbation of chronic obstructive pulmonary disease or a restrictive disease, pulmonary infections, acute respiratory distress syndrome and cardiogenic pulmonary oedema. Consequently, the larger part of books, monographs and reviews on acute respiratory problems deal with these specific topics.

However, in our daily practice, we have to face other important, although less frequent, respiratory emergencies, such as haemoptysis, ingestion of foreign bodies, pneumothorax, drowning and inhalation injury. Indeed, some peculiar aspects, such as paediatric respiratory emergencies and the occurrence of respiratory failure during pregnancy, are very seldom assessed if they are not covered in specific publications.

The idea of this Monograph, published by the European Respiratory Society, was to fill this gap, giving the readers the opportunity to have a complete overview of the respiratory emergencies that account for $\sim 20-30 \%$ of all the emergency admissions to hospital.

The guest editors have asked international experts to not only write an up-to-date review of their specialist subject, but also, when feasible, to give some personal insights based on their long experience in the field.

A great amount of effort has been put in by everyone involved in the project, from the publishers to the authors. Have we succeeded? The answer is down to the readers! 